\title{
Erratum: "Reflection and Absorption Characteristics of Various Physical Objects in a Millimeter Radio-Wave Range" [Doklady Physics 45 (10), 510 (2001)]
}

\section{I. Zagatin, V. V. Meriakri, G. S. Misezhnikov,} E. E. Chigryă̌, and V. B. Shteĭnshleĭger

In our paper "Reflection and Absorption Characteristics of Various Physical Objects in a Millimeter RadioWave Range," which was published in Doklady Physics, vol. 45, no. 10, pp. 510-511, the beginning of the last item should be red as "The results of the measurements of the reflection coefficient...."

V.I. Zagatin, V.V. Meriakri,

G.S. Misezhnikov, E.E. Chigryă,

V.B. Shteŭnshleı̆ger 